\title{
Form and Substance in Equity
}

\author{
Ben McFarlane
}

\section{$1 \quad$ INTRODUCTION}

The argument of this chapter is that the distinction between form and substance is crucial to understanding and justifying the distinction between common law and equity and, more fundamentally, the distinction between two different types of legal rule. ${ }^{1}$ The terms 'form' and 'substance' are used here in a particular sense: 'form' refers to the type of legal relation arising from the parties' dealings and the application of particular rules to those dealings; 'substance' refers to the effect in practice of such dealings and rules. The argument here is not based on the notion that "equity looks to the substance not the form". ${ }^{2}$ In fact, this chapter asserts something close to the opposite: the key to understanding much equitable intervention in the law of obligations lies in paying very close attention to the form of the legal relations involved.

Three main points will be made. First, in seeking to understand and justify many equitable rules, ${ }^{3}$ it is crucial to see such rules as controlling, in favour of one party, $\mathrm{B}$, the enforcement or acquisition of a right by another party, A. ${ }^{4}$ Equity, in that specific sense, functions as second order or meta-law. ${ }^{5}$ Second, this means that certain equitable rules often seen as having an effect very similar to that of particular common law rules must in fact be carefully distinguished from their supposed common law "equivalents". ${ }^{6}$ Third, once certain rules (whether originating

\footnotetext{
1 'Legal rule', and 'legal relation', will be used here to encompass both common law and equitable rules.

${ }^{2}$ As noted by J Heydon, M Leeming and P Turner (eds) Meagher, Gummow and Lehane's Equity: Doctrines and Remedies $5^{\text {th }}$ edn (Sydney, LexisNexis, 2015) [3-145], this is "another wording" of the maxim that "equity looks to the intent, rather than to the form". See too J McGhee (ed) Snell's Equity, 33 ${ }^{\text {rd }}$ edn, (London, Sweet \& Maxwell, 2015), [5-013]-[5-014].

${ }^{3}$ This chapter does not consider all equitable rules; in particular, remedial rules are beyond its scope.

${ }^{4}$ As stated by Lord Cairns in Hughes v Metropolitan Rwy Co (1877) 2 App Cas 439, 448: “[the] first principle upon which all Court of Equity proceed [is that]...the person who might otherwise have enforced those rights will not be allowed to enforce them where it would be inequitable having regard to the dealings between the parties."

${ }^{5}$ For equity as operating in a second order, or meta way see e.g. H Smith, 'Equitable Defences as Meta-Law' and R Stevens, 'Set-Off and the Nature of Equity' in P Davies, S Douglas and J Goudkamp (eds) Defences in Equity (Oxford, Hart, 2018).
}

${ }^{6}$ See e.g. the discussion in section 5 below of equitable estoppel. 
in equity or not) are identified as regulating, in B's favour, the enforcement or acquisition of a right by $\mathrm{A}$, this has consequences for how those rules might be justified. ${ }^{7} \mathrm{~A}$ focus on form is thus a necessary preliminary to a consideration of the substantive justifications of particular rules.

These three points, taken together, can be seen as emphasizing the importance of means (form) as well as ends (substance). In many cases, an equitable claim is of value because it allows a party to secure many of the practical benefits that are associated with a similar common law claim. If, for example, A holds a property right on trust for B, it might be thought that B's right is in many ways "as good as" ownership of the relevant property, so that B is the "real" owner of that property. B's vulnerability to a purchaser from A invoking the defence of bona fide purchase of a legal estate for value without notice might be seen as the major weakness of B's position but, where B has an equitable interest in land which can be protected by an entry in the register, even that difference may disappear: an equitable lease, for example, arising under the doctrine in Walsh $v$ Lonsdale, ${ }^{8}$ is thus often regarded as being "as good as" a legal lease. ${ }^{9}$ The very success of equity in securing such benefits for B may lead us to regard B's equitable right as simply a somewhat watered-down version of a common law original. This then raises the difficult question of why any legal system should have two different sets of rules governing the acquisition of very similar rights. The argument of this chapter, however, is that similarities in the practical outcomes of particular rules should not blind us to the different ways in which such rules achieve those outcomes. ${ }^{10}$ Looking to the form in this sense is important for both practical and conceptual reasons. Practically, the fact that two particular rules (e.g. as to the effect of legal property rights, and as to the effect of equitable interests) often lead to the same outcome does not mean that those rules will always do so. Conceptually, it helps us to see that the law as a whole has a number of different resources, and can thus respond to problems in

\footnotetext{
${ }^{7}$ See e.g. the discussion in section 4 below of the mistaken transfer of rights.

8 (1882) 21 Ch D 9 (CA).

${ }^{9}$ See e.g. $R v$ Tower Hamlets, ex $p$ von Goetz [1999] 1 QB 2019 (CA), 1023, where Mummery LJ described the right of a party with an equitable lease as "for all practical purposes, an interest as good as a legal interest."

10 The chapter thus picks up on a point made by Maitland in relation to the trust. In 'Trust and Corporation', Maitland stated that: 'I believe that for the ordinary thought of Englishmen 'equitable ownership' is just ownership pure and simple, though it is subject to a peculiar, technical and not very intelligible rule in favour of bona fide pruchasers': see D. Runciman and M. Ryan (eds) Maitland: State, Trust and Corporation (Cambridge: CUP, 2003) 94. In that essay (first published in German: Maitland, 'Trust and Corporation' (1905) Grunhut's Zeitschrift fur das Privat- and Offentliche Recht 1) and in his Equity: A Course of Lectures (2nd ed, 1936, A H Chaytor \& W J Whittaker, eds, revised by John Brunyate, CUP, Cambridge, 1909), however, Maitland identified important further differences between the rights of a beneficiary and those of an unencumbered owner.
} 
more nuanced and various ways. It is not simply a case, for example, of deciding if there is or is not a valid contract between A and B; it is possible to say that there is a contract, but to allow B a means of controlling A's acquisition or enforcement of a right under that contract. ${ }^{11}$ Further, rules that thus control the acquisition or enforcement of rights may have distinct justifications: they may be necessary, for example, to prevent other rules operating to cause an injustice.

It would be no surprise if this function of controlling, in B's favour, the acquisition or enforcement of A's rights were to be particularly associated with equity. It accords both with the notion of equity as a supplementary, or secondary system, and with the ancient idea that equity can operate to correct problems caused by the generality of primary rules. ${ }^{12}$ Two warnings should, however, be noted. First, it is not argued here that rules controlling the acquisition or enforcement of rights are recognized only by equity; second, it is not argued that equity consists only of such rules. The key distinction made here is not between common law and equity as such, but rather between primary rules that define the parties' rights, and secondary rules that control, in favour of B specifically, A's acquisition or enforcement of rights. There is no reason, either historically or in the present law, why the common law cannot also recognize such secondary rules. ${ }^{13}$ The ability of equity, historically, to recognize primary rules is a more difficult question, but it is clear that there are modern cases in which equity has gone beyond its traditional function of controlling the acquisition and enforcement of rights. ${ }^{14}$ As a result, it is not argued here that the function can explain all of modern equity. It is rather argued that it is at least important in understanding many areas in which equity has an impact on the law of obligations. Space precludes consideration here of all such examples, but three will be considered: in section 3 , the effect of a trust on the obligations of third parties; in section

\footnotetext{
${ }^{11}$ This occurs, for example, when, as a result of A's innocent pre-contractual misrepresentation, B has an equitable power to rescind a valid contract: see e.g. Redgrave v Hurd (1881-2) LR 20 Ch D 1 (CA).

${ }^{12}$ See D Klimchuk, 'Equity and the Rule of Law' in L Austin \& D Klimchuk (eds) Private Law and the Rule of Law (Oxford, OUP, 2014) discussing Aristotle's account in Nicomachean Ethics, trans JO Urmson and WD Ross in The Complete Works of Aristotle, ed Barnes, ii.1796 of the 'equitable' as 'a correction of law where it is defective owing to its universality.'

${ }^{13}$ As noted in section 5 below, common law rules of waiver are an example of rules that regulate in C's favour the enforcement of a right by D. A common law power to rescind a contract entered into as a result of duress or fraud is a further example, although its pedigree has been doubted: see W Swadling, 'Rescission, Property, and the Common Law' (2005) 121 LQR 123.

${ }^{14}$ The development of breach of confidence to include misuse of private information and other breaches of privacy (such breaches often being referred to as 'torts': see e.g. TLT v Secretary of State for the Home Dept [2018] EWCA Civ 2217, [15], [18] and [26] (Gross LJ)) provides one example: see further J Goldberg \& H Smith, 'Wrongful Fusion: Equity and Tort' in J Goldberg, H Smith, and P Turner (eds) Equity and Law: Fusion and Fission (Cambridge, CUP, forthcoming).
} 
4, restitutionary claims based on mistaken transfers; in section 5, equitable estoppel. First, however, it is necessary briefly to explain how the view put forward here relates to the traditional view that equity looks to substance not form.

\section{SUBSTANCE AND FORM IN EQUITY: AN INITIAL EXAMPLE}

Lord Romilly MR, in Parkin v Thorold, stated that "Courts of Equity make a distinction in all cases between that which is matter of substance and that which is matter of form". ${ }^{15}$ So even if a contract makes "positive and unambiguous" provision that property is to belong to the mortgagee if a debt is not repaid on time, a Court of Equity "treats the substance of the contract to be a security for the repayment of money advanced, and that portion of the contract which gives the estate to the mortgagee as mere form." ${ }^{16}$ If, as in Parkin itself, a court finds that a term of a contract allowing A to gain or retain property is intended to operate as security for the performance of a duty, the court can characterize A's interest in the property as a security right, and prevent it being used by A for other purposes. This remains true today even for a contract concluded by well-advised commercial parties: the clear terms of a contract can, it seems, be disregarded by a court where those terms would allow a party to take advantage of a security right to gain the borrower's property even when the borrower is able, in substance, to perform the secured duty. ${ }^{17}$

It is important in such cases to distinguish between two stages of the court's reasoning. First, there is a question as to the construction of the contract: has B transferred a right to A, or given A a new right, by way of security? At this stage, of course, a court of equity need not be taken in by a party's attempt to present a transaction in a particular light, if in fact the objectively manifested intentions of the parties lead to a different conclusion. This point can be presented as depending on a preference for substance over form, but such a preference is clearly not distinctive to equity. In Parkin itself, Lord Romilly MR stated that: "A contract is undoubtedly to be construed alike both in equity and at law"18 and there is no shortage of common law

\footnotetext{
15 (1852) 16 Beav 59, 66; 51 ER 698, 701.

16 (1852) 16 Beav 59, 686; 51 ER 698, 702.

${ }^{17}$ See e.g. Cukurova Finance International Ltd v Alfa Telecom Turkey Ltd [2016] AC 923 (PC), esp at [125][126] (Lord Neuberger).

18 (1852) 16 Beav 59, 66-7; 51 ER 698, 701.
} 
examples where a court has looked beyond a particular party's characterization of a transaction in order to establish the parties' rights. ${ }^{19}$ Further, whether at law or in equity, the limits on the court's characterization come from the objectively manifested intentions of the parties and so, for example, neither equity nor common law can look beyond a clear expression of such intentions. ${ }^{20}$ There is no relevant "substance" beyond establishing such intentions, and courts do not look at "substance" in the sense of the wider function or practical effect of the transaction. For example, it may be clear to all that a transaction has been structured as, for example, a lease or a hire-purchase agreement, or as a sale subject to retention of title, in order to serve the same economic function as giving A a security right; but if the transaction has genuinely taken such a form, then, absent a statutory direction to the contrary, equity and common law courts will not apply rules (such as those requiring registration) that would apply to a security right such as an equitable charge. ${ }^{21}$

So, whilst the initial stage of the court's reasoning (construction of the contract) might be said to involve a preference for substance over form, that characterization is potentially misleading, first because it does not show anything distinctive about equity as opposed to common law, and second because the preference is not for substance in a general sense of the function or effect of the transaction, but is simply for giving effect to the parties' objective intentions. The second stage of the court's reasoning in a case such as Parkin v Thorold is of more significance to the argument made in this chapter. Once the parties' rights have been established through construction of the contract, it is possible then that a particular principle will control, in B's favour, the way in which A may exercise A's rights. The point in Parkin, for example, is that, once A's right is characterized as a security right, A's assertion of that right against B can be controlled to ensure that A does not use it for a different purpose. The form of equity's intervention consists of controlling A's exercise of a particular right: in this case, the right is controlled because of the basis on which A acquired it. There is an element of 'substance', of course, in the operation of the equitable rule: where the right secured is a duty of B to make payment to A, B is allowed to redeem by making a late payment of the secured sum, provided

\footnotetext{
${ }^{19}$ See e.g. Street v Mountford [1985] AC 809 (HL), discussed by B Haecker in chapter XX, Orion Finance v Crown Financial Management [1996] 2 BCLC 78 (CA), and the discussion in Welsh Development Agency $v$ Export Finance Company [1992] BCLC 148, 186 (CA).

${ }^{20}$ See e.g. Union Eagle Ltd v Golden Achievement Ltd [1997] AC 514 (PC); Byrnes v Kendle (2011) 243 CLR 253.

${ }^{21}$ See e.g. Lloyds \& Scottish Finance v Cyril Lord Carpets Sales [1992] BCLC 609 (HL); Associated Alloys Pty Ltd v ACN 001452106 Pty Ltd (200) 202 CLR 588.
} 
A's interests and costs are also met. In 'substance', in such a case, B can be said to have performed the primary duty, even if the precise requirements of that duty have not been met. It is important to note, however, the limited role played by 'substance' and how the justification for equitable intervention is the existence of a specific reason to control the exercise of A's right.

The operation of the equitable jurisdiction to relieve against forfeiture thus provides an example of equitable intervention that takes the specific form of controlling, in favour of $\mathrm{B}$, the assertion of a right by A. The High Court of Australia's analysis of the rule against penalties in Andrews $v$ Australia and New Zealand Banking Group Ltd ${ }^{22}$ is consistent with such a view of equitable intervention and indeed uses it as a justification for the much-debated rule against penalties. In contrast, the Supreme Court in Cavendish Square Holding BV v Makdessi ${ }^{23}$ preferred to emphasise the common law basis of the modern rule against penalties. The point here is not to express a view on whether the rule should best be understood, either historically ${ }^{24}$ or in its current operation, as common law or equitable rule, ${ }^{25}$ but rather to note how the equitable emphasis in Andrews depends on a particular conceptualization of the rule, which in turn fits with the analysis of this chapter. So, in Andrews, "[i]t is the availability of compensation which generates the "equity' upon which the court intervenes" as, given the contested stipulation is "in the nature of security", ${ }^{26}$ it would be an abuse if A could insist on asserting that right beyond the extent required to provide compensation for the non-occurrence of the primary, secured outcome. Where a term is thus identified as a penalty, a court can control A's assertion of the right to ensure that $\mathrm{A}$ does not use the right to make a disproportionate gain, or to inflict a disproportionate loss on B. In some cases, therefore, a court may allow A to enforce the right,

\footnotetext{
22 (2012) 247 CLR 205.

${ }^{23}$ [2016] AC 1172 (SC).

${ }^{24}$ For a convincing account of the equitable origin and nature of the rule, see P Turner, 'Lex Sequitur Equitatem: Fusion and the Penalty Doctrine' in J Goldberg, H Smith, and P Turner (eds) Equity and Law: Fusion and Fission (Cambridge, CUP, forthcoming).

${ }^{25}$ Or, indeed, whether there are two separate rules, one deriving from common law and one from equity, which was the basis on which Gordon J proceeded in Paccioco v Australia and New Zealand Banking Group Ltd (2014) 309 ALR 249. Certainly, the Andrews decision is not the last word in Australia, as the High Court's decision in Paccioco (2016) 258 CLR 525 plays down possible differences between the Australian position and that in England following Cavendish. For discussion, see N Tiverios, 'A Restatement of Relief against Contractual Penalties (I) and (II)' (2017) $11 \mathrm{~J}$ Eq 1 and 185.
} 
but only to a limited extent. ${ }^{27}$ In contrast, in Cavendish, the Supreme Court did not regard the penalties doctrine as limiting the assertion of an acknowledged right of $\mathrm{A}$, but rather saw it as denying $\mathrm{A}$ and $\mathrm{B}$ the power to create in A a particular type of contractual right. On that view, a penal stipulation seems to be simply void: there is no primary right to be controlled, and the doctrine can be seen, like the doctrine of illegality, as a limit on the parties' powers to create contractual rights. As a result, there is no possibility of the court permitting limited enforcement of the penalty.

Clearly then, important practical differences flow from the different characterizations of the penalties rule adopted in Australia and in England. It is not the case, however, that the court in Andrews, unlike that in Cavendish, was willing to ignore the actual form of the parties' legal relations in order to respond to a broader practical reality: indeed, the analysis in Andrews, ${ }^{28}$ like that in Cavendish, ${ }^{29}$ makes clear that if the parties choose to arrange a transaction so that e.g. a payment must be made by B to A not as a result of the failure of a stipulation, but rather as a fee for some additional benefit conferred by A, then the penalties doctrine does not apply. Nor does the difference between an equitable and a common law analysis mean, in itself, that the Australian courts have more discretion or flexibility when deciding if an impugned term is a penalty: the test in each case is whether the effect of the term is disproportionate to the legitimate interests of $A .{ }^{30}$ Rather, the practical differences flow from the particular form which intervention takes: is it a case, as is the Andrews view, of controlling, in favour of $\mathrm{B}$, the enforcement of A's right; or is it a case, as in the Cavendish view, of simply denying the parties the power to create a particular remedial regime? The crucial question is thus be as to the form of the rule, rather than as to its derivation from either equity or common law.

\footnotetext{
${ }^{27}$ See e.g. the approach of Deane J and Dawson J in AMEV-UDC Finance Ltd v Austin (1986) 162 CLR 170.

28 (2012) 247 CLR 205, [80]-[92].

${ }^{29}$ [2016] AC 1172. Although note the somewhat unclear reference to a 'disguised penalty' at [258] (Lord Hodge) and to a 'disguised punishment' at [77] (Lords Sumption and Neuberger).

${ }^{30}$ See Cavendish (n XX) [2016] AC 1172, [22], [28], [31]-[32] (Lords Neuberger and Sumption) and Paccioco (n XX) [29], [57]-[58] (Kiefel J).
} 
It was contended in section 2 above that regarding the penalties rule as 'equitable' is linked to conceiving of the rule as having a particular form: it allows the court to control, in favour of one party, another party's enforcement of a right. It will be argued in this section that understanding the obligations imposed by trusts on third parties similarly depends on seeing the right of the beneficiary of a trust as having a particular form: the beneficiary does not have a right to the trust property itself, but rather benefits from rules that control another's acquisition or enforcement of rights.

\subsection{Obligations of third parties interfering with trust property}

In Shell UK Ltd v Total UK Ltd, ${ }^{31}$ a large explosion, resulting in part from the carelessness of the defendant, $\mathrm{X}$, damaged fuel storage and pipeline facilities used by B, causing B to suffer financial loss as a result of its inability to supply customers. The difficulty for B was that legal title to the relevant property was held by trustees (T) on trust for B, and not by B itself. Such was the legal form of the parties' arrangements, arrived at when B, along with other companies, co-operated to establish the facilities. It was held at first instance that, as B had no legal ownership or possessory title to the property, the loss it had suffered as a result of the damage was purely economic loss, and so the general "exclusionary rule" applied, meaning that X was not liable for having carelessly caused such loss. ${ }^{32}$ The Court of Appeal, in contrast, allowed B's claim for substantial damages. It avowedly looked beyond the legal form of the parties' arrangements to the substance of the position, stating that: ${ }^{33}$

it is legalistic to deny [B] a right to recovery by reference to the exclusionary rule. It is, after all, [B] who is (along with [the other three beneficiaries]) the 'real' owner, the 'legal' owner being little more than a bare trustee of the pipelines.

\footnotetext{
${ }^{31}$ [2011] QB 86 (CA).

${ }^{32}$ The first instance decision is reported as Colour Quest Ltd v Total Downstream Ltd [2009] EWHC 540 (Comm).

${ }^{33}$ Shell (n XX) at [132].
} 
The decision in Shell has met with much disapproval ${ }^{34}$ and has some potentially unwelcome practical effects: for example, if a large number of beneficiaries are making use of property in different ways, is $\mathrm{X}$, following one act of carelessness, liable for all the foreseeable economic loss of each of those beneficiaries? Certainly, where a stranger carelessly damages the trust property, the orthodox position is that this is a wrong against the trustee rather than against the beneficiary. ${ }^{35}$ It is true that a beneficiary of trust may enjoy the major practical benefits associated with the trust property and, indeed, will often receive the property itself at some point. ${ }^{36}$ Yet this does not mean that, during the currency of the trust, we should simply regard the beneficiary as having the same rights as an unencumbered owner of the property (or even a slightly weaker version of such rights). To do so would be to ignore the form of legal relations involved in a trust. Title to the trust property is vested in the trustee and the intervention of equity consists of recognizing a duty on the trustee that relates specifically to the trust property. Equity does not ask: "Who is the owner of the property?" and then give a different answer to that provided by common law. ${ }^{37}$ Rather, equity accepts that $\mathrm{T}$, the trustee, holds title to the property, but at the same time recognizes that $\mathrm{T}$ is under a duty to the beneficiary, $\mathrm{B}$, and that duty limits (in favour of B) the ways in which T may exercise or enjoy the trust property.

The 'proprietary' nature of B's right then comes from the fact that equity is also prepared to control, in B's favour, the exercise or enjoyment of the same right ${ }^{38}$ by a successor in title to T's right, if that successor's conscience is affected at the time he holds that right. ${ }^{39}$ This is easy to explain if we focus on equity's role in controlling T's assertion of a right: the successor in

\footnotetext{
${ }^{34}$ See e.g. K Low, Equitable Title and Economic Loss (2010) 126 LQR 507; P Turner, 'Consequential Economic Loss and the Trust Beneficiary' [2010] CLJ 445; J Edelman, 'Two Fundamental Questions for the Law of Trusts' (2013) 129 LQR 66.

${ }^{35}$ See e.g. g. The Lord Compton's Case (1587) 3 Leo 197; Leigh and Sillavan Ltd. v. Aliakmon Shipping Co. Ltd. (The Aliakmon) [1986] AC 785 (HL); Restatement (Third) of Trusts (2003) §§ 107-108.

${ }^{36}$ As pointed out by e.g. J Penner, 'The (True) Nature of a Beneficiary's Proprietary Interest Under a Trust' (2014) 27 Can J L Juris 473, 485.

${ }^{37}$ Maitland memorably claimed that such a contradiction between common law and equity would give rise to "civil war and utter anarchy": F Maitland, Equity: A Course of Lectures (2nd ed, 1936, A H Chaytor \& W J Whittaker, eds, revised by John Brunyate, CUP, Cambridge, 1909) Lecture II.

${ }^{38}$ Or to a right that counts as a product of T's initial right (as where, for example, T grants a lease of trust property to the third party).

${ }^{39}$ See e.g. the analysis of Lloyd LJ in Independent Trustee Services Ltd v GP Noble Trustees Ltd [2013] Ch 91 (CA), [75]-[81]. The importance of the third party's conscience being affected is confirmed by the language used by Lord Sumption in Akers v Samba Financial Group [2017] AC 424, [89].
} 
title to $\mathrm{T}$ acquires a right and so the form of legal relations as between $\mathrm{B}$ and $\mathrm{T}$ may be replicated, to at least some extent, as between B and the successor in title. There is, therefore, no reason to assume that a stranger, who simply interferes with the trust property without acquiring any right, is under any immediate duty to the beneficiary. Indeed, the rules as to the acquisition of an interest under a trust would be difficult to explain if such duties arose: for example, registration is generally a requirement for the acquisition of a legal property right in land, ${ }^{40}$ whereas no such publicity is needed for the acquisition of an equitable interest in land.

The better view, it is suggested, is that the duties owed by third parties to an owner of property are not changed if the owner then declares a trust of the property. ${ }^{41}$ Such a declaration does of course change the previous legal relations as between the trustee and the party who is now the beneficiary, and any damages recovered by the trustee from a third party interfering with the property, for example for the cost of repairs to the property, would then also be held on trust. Such damages are proceeds of the right held on trust and if the trustee were to refuse, in breach of his duty of the beneficiary, to bring a claim, then the beneficiary can join an action against the trustee with the trustee's action against the stranger. ${ }^{42}$ The need for joinder of the trustee is not an empty formality, however, as it is, crucially, the trustee's right that is enforced against the stranger. ${ }^{43}$ This means, for example, that consequential loss suffered only by the beneficiary as a result of the damage to the property should not be recoverable.

One difficulty with the Court of Appeal's reasoning in the Shell case is that it sees the claim against $\mathrm{X}$ as in fact the claim of $\mathrm{B}$, the beneficiary of the trust (thus allowing for recovery of B's consequential loss) whilst also insisting on joinder of the trustee, ${ }^{44}$ seemingly regarding such joinder as merely a mechanism to prevent double recovery by $\mathrm{B}$. This misunderstands the purpose of the joinder. A further, more significant difficulty with the court's reasoning is that,

\footnotetext{
${ }^{40}$ See e.g. Land Registration Act 2002, ss 4 and 27; Transfer of Land Act (Vic) 1958, s 40.

${ }^{41}$ See too P Matthews, 'The Compatibility of the Trust with the Civil Law Notion of Property' in L Smith (ed) The Worlds of the Trust (Cambridge, CUP, 2013), noting that T retains his or her general entitlement to the trust property.

${ }^{42}$ Employing the Vandepitte procedure, named for Vandepitte v Preferred Action Insurance Co [1933] AC 70.

43 This also explains why legislative provision is required to protect beneficiaries in a case where a limitation period has expired against trustees of land, and why that protection consists of preserving the estate of the trustees: Limitation Act 1980, s 18(3).
}

${ }^{44}$ [2011] QB 86 (CA) [144] 
having correctly characterized the losses suffered by B as purely economic loss, it found that B could rely on an exception to the "exclusionary rule" preventing recovery of such losses, as: "[b]eneficial ownership of the damaged property goes well beyond contractual or noncontractual dependence on the damaged property and does indeed constitute a special relationship of the kind required." ${ }^{45}$ The problem, of course, ${ }^{46}$ is that the special relationship required for the recovery of pure economic loss must be a relationship between the claimant and the defendant (in Shell, therefore, between B and X), whereas the existence of the trust simply shows there is a particular relationship between B and the trustee, $\mathrm{T}^{47}$

This flaw in the reasoning in Shell can be connected to a failure to scrutinize the form of legal relations involved in a trust, leading to an under-estimation of the rights of the trustee and an exaggeration of the rights of the beneficiary. It is tempting to say that the rights of a trustee are in some sense diminished as compared to the rights of an unencumbered owner of property. We might say, for example, that a trustee is not free to use the property for his or her own benefit, and so, for example, does not have the power to take a renewal of a lease held on trust ${ }^{48}$ we might also say that it is then the beneficiary who has the right to the benefit of, or value of, the trust property. This overlooks the fact that the existence of the trust only changes the position of the trustee as regards the beneficiary: as regards all other parties, the trustee remains free to assert the rights that come with holding the property. A classic example of this point is the decision in Burgess $v$ Wheate $:{ }^{49}$ when a beneficiary died without heirs, so that there was no longer anyone with a right correlating to the trustee's duty, the trustee was then free to use the property for his own benefit; it was not the case that the beneficial interest instead passed to another under the rules on escheat. The point here is that, in recognizing the beneficiary's rights, equity is not carving out any distinct interest and thus reducing the interest

\footnotetext{
45 [2011] QB 86 (CA) [134].

46 See too B McFarlane, 'Avoiding Anarchy? Common Law v Equity \& Maitland v Hohfeld' in J Goldberg, H Smith, and P Turner (eds) Equity and Law: Fusion and Fission (Cambridge, CUP, forthcoming). Note that the Supreme Court gave permission for an appeal against the Court of Appeal's decision in the Shell case, but the appeal was settled. Even if D had succeeded on the point as to the negligence claim, $\mathrm{C}$ was also pursuing a claim against $\mathrm{D}$ based on public nuisance.

${ }^{47}$ The position is different where D has expressly or impliedly assumed responsibility to C (as may occur where, for example, D, knowing of the trust in C's favour, contracts with $\mathrm{T}$ to perform a service for the benefit of C: see e.g. Chappell v. Somers \& Blake [2004] Ch 19).

${ }^{48}$ See e.g. Keech v Sandford (1726) Sel Cas Ch 61, 25 ER 223.

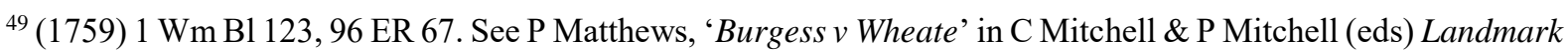
Cases in Equity (Oxford, Hart, 2012).
} 
of the trustee; rather, the trustee's right remains, but is now encumbered by a duty owed to the beneficiary. ${ }^{50}$ At the level of practical effect, the trust, in substance may allocate value as between trustee and beneficiary; but at the level of legal form, it involves no such division. ${ }^{51}$

\subsection{Obligations of recipients of trust property}

The specific question to be examined here concerns the circumstances in which D (a third party receiving trust property from the trustee) can come under a liability to $\mathrm{B}$, the beneficiary of the trust. Let us first assume that the transfer is not one that the trustee has authority to make under the terms of the trust (and so does not overreach B's right) and also that D is not a bona fide purchaser for value of the trust property (and so is not thus immune from a claim of B). It is clear that if $\mathrm{D}$ is aware of the fact that the transfer was in breach of trust, and still holds the trust property (or a right that can be identified as its product), D comes under a duty not to use that right for his or her own benefit, and so must account to B for it. If D still has that property when B's claim is determined, D can be ordered to transfer that property to a new trustee, or, in an appropriate case ${ }^{52}$ to $\mathrm{B}$; if D no longer has that property, because he or she disposed of it after becoming aware of the initial breach of trust, D is liable to account to B as a constructive trustee. ${ }^{53}$ Such liability is often referred to as arising in knowing receipt, although D's knowledge need not coincide with the receipt, as long as it arises whilst D still has the trust property or a right identifiable as its product.

It has been argued, for example by Birks, ${ }^{54}$ that a strict liability restitutionary claim, subject to the standard defences such as change of position, should also be available to B against D. Such

\footnotetext{
50 The actual result in Burgess was modified by statute in 1884. See now Law of Property Act 1922, s 148, Administration of Estates Act 1925, ss 45(1)(d), 46(1)(vi). The reasoning as to the nature of the trust, however, may remain relevant: see e.g. Brennan J in DKLR Holding Co (No 2) Pty Ltd v Commissioner of Stamp Duties (1982) 149 CLR 431, 474.

${ }^{51}$ See N Jones, 'Trusts in England After the Statute of Uses: A View from the Sixteenth Century' in Itinera Fiduciae: Trust and Treuhand in Historical Perspective (eds R Helmholz and R Zimmerman, Berlin: Duncker \& Humblot, 1998) 190.

52 As when the initial trust is simply a bare trust in favour of B.

${ }^{53}$ For a description of the process of taking an account, as a means of enforcing such a liability, see Lewison $\mathrm{J}$ in Ultraframe (UK) Ltd v Fielding [2005] EWHC 1638 (Ch) [1513].

${ }^{54}$ See e.g. Birks, Unjust Enrichment $2^{\text {nd }}$ edn (Oxford, OUP, 2005) 156-158. See too Lord Nicholls, 'Knowing Receipt: The Need for a New Landmark' in WR Cornish et al (eds) Restitution: Past, Present and Future: Essays
} 
a claim would be useful to B in the case where, although D disposed of the trust property and any traceable product of it before becoming aware of the breach of trust, D nonetheless retains a benefit from the receipt of the trust property and would not be able to rely on a change of position as a complete defence to B's claim. This might occur, for example, where D innocently disposed of the trust property in order to make an expenditure which D would have made in any case. One of Birks' contentions was that equity should follow the common law in recognizing such a restitutionary claim, as it makes little sense to deny it to a beneficiary, given it is available to an unencumbered holder of a right transferred without authority; ${ }^{55}$ it might also be said that it is the beneficiary, rather than the trustee, who has the right to the value of the trust property, and so any enrichment of the recipient is at the beneficiary's expense. ${ }^{56}$

The preceding analysis reveals a difficulty in these arguments and thus a justification for the current denial of such a strict liability claim across the common law world. ${ }^{57}$ It may be true that, as a matter of practical reality, the existence of a trust can secure to the beneficiary the enjoyment or value of the trust property. Nonetheless, it is not true, as a matter of the parties' legal relations, to say that the beneficiary has an abstract right to the value of the trust property: B's enjoyment depends on B's ability to control a specific right held by another and, where third parties are concerned, that ability is limited to cases where the third party holds a relevant right with knowledge of the initial breach of trust. The transfer of the trust property from the trustee to $\mathrm{D}$ does not involve any transfer of a right from $\mathrm{B}$ to $\mathrm{D}$. The point is a similar one to that made in section 3.1 in relation to Shell $v$ Total: the existence of the trust means that the trustee is under a duty to the beneficiary in relation to the trust property, but it does not otherwise change the position of the trustee as regards third parties. Whatever the terms of the trust, the trustee does have the power, as holder of the trust property, to make a valid transfer of that property.

\footnotetext{
in Honour of Gareth Jones (Oxford, Hart, 1998) 321; the decision of the New South Wales Court of Appeal in Farah Constructions Pty Ltd v Say-Dee Pty Ltd [2005] NSWCA 309; J Edelman and E Bant, Unjust Enrichment $2^{\text {nd }}$ edn (Oxford, Hart, 2016) 288-291.

${ }^{55}$ See e.g. Birks, Unjust Enrichment $2^{\text {nd }}$ edn (Oxford, OUP, 2005) 156-158.

${ }^{56}$ Farah Constructions Pty Ltd v Say-Dee Pty Ltd [2005] NSWCA 309 [233]. See too JB Ames 'Purchaser for Value Without Notice' (1887) 1 HLR 1.

${ }^{57}$ See e.g. BCCI v Akindele [2001] Ch 437 (CA); Farah Constructions Pty Ltd v Say-Dee Pty Ltd (2007) 230 CLR 89; Citadel General Insurance Co v Lloyds Bank Canada [1997] 3 SCR 805. The position in the United States is less clear: it is assumed in the Restatement (Third) of Restitution (as in the First and Second Restatements) that a strict liability restitutonary claim is available in such a case (s 17 , comment c, illustration 9) but no authority is cited.
} 
This means that the argument for a strict liability restitutionary claim faces two linked problems. First, the right acquired by the recipient, D, is acquired from the trustee, not the beneficiary: there is no distinct 'right to enjoyment' which D purports to acquire from $\mathrm{B}$. This clearly distinguishes the case from that where, for example, the claimant makes a mistaken payment to the defendant. Second, there is a difficulty in locating an 'unjust factor': B has not exercised any power at all, or made any transfer which B could seek to reverse, and so there is no flawed transfer to which B can point. Of course, the transfer by $\mathrm{T}$ to $\mathrm{D}$ may involve a breach of trust, and be unauthorized under the terms of the trust, but it is hard to see why that in itself should give rise to a strict liability restitutionary claim. ${ }^{58}$ The substance (in the sense of practical effect) of the T's transfer in breach of trust may indeed be that B has lost out, and D has gained, without B having consented to such a state of affairs, but it is the form of the parties' legal relations that must rather be considered in determining if a claim can be made. This raises a broader point about restitutionary claims, which will be considered in section 3 below.

3.3 Rights of an insolvent beneficiary to set aside a transaction between the trustee and a third party

The analysis above is consistent with the Supreme Court's decision in Akers v Samba, ${ }^{59}$ which also considers the impact of a trust on a third party. The court's analysis proceeded on the assumption that $\mathrm{T}$ had purported to declare himself a trustee for B, a Cayman Islands company, of shares in a Saudi company, and to have Cayman law govern the trust. After a winding-up presentation had been presented in the Cayman Islands against B, T had transferred the shares to D. It appeared that under Saudi law, D would therefore receive good title to the shares, free from any claim of B. B's liquidators, however, relied on s 127 of the Insolvency Act 1986, which states that, in a winding up by the court, "any disposition of the company's

\footnotetext{
${ }^{58}$ If the recipient retains the trust property or its traceable proceeds at a point when he acquires knowledge of the breach of trust, he will then be under a duty to the beneficiary in relation to the property, and such a duty can be enforced either by an equitable 'proprietary' claim (see e.g. Agip (Africa) Ltd v Jackson [1990] 1 Ch 265, 290 (Millett J)), or by an action in knowing receipt. Neither claim though is available against the recipient who, whilst still retaining a benefit from the receipt, disposed of the trust property and any traceable proceeds of it before acquiring knowledge of the breach (see e.g. Agip (Africa) Ltd v Jackson [1990] 1 Ch 265, 290 (Millett J)).
}

59 [2017] AC 424 (SC). 
property...made after the commencement of the winding up is, unless the court otherwise orders, void...".

For present purposes, there are two significant aspects to the reasoning of the Supreme Court. First, it was accepted that the court could uphold the validity of a trust of shares even if it were the case that Saudi law, as the lex situs of the shares, had no concept of the trust, or of a division between legal and equitable entitlements. ${ }^{60}$ The explanation consistently provided by the authorities is that the recognition of a trust does not, in itself, undermine the position under the lex situs, as it does not deny that $\mathrm{T}$ has a proprietary entitlement, but simply recognizes that $\mathrm{T}$ is under a duty to B in relation to T's assertion of that entitlement. ${ }^{61}$ The relationship of English law to the lex situs provides a modern parallel to the relationship of equity to common law in the early development of the use, and then the trust. There is a sense in which the common law recognized $\mathrm{T}$ as simply an unencumbered holder of a property right. As Maitland noted, ${ }^{62}$ equity did not contradict or undermine the common law, as it did not deny that $\mathrm{T}$ held that property right, but rather imposed a duty on $\mathrm{T}$ in relation to it. On this view, the reason why Cayman law can recognize a trust of Saudi shares without undermining the lex situs also explains why a court of equity can recognize a trust of English land without undermining the common law. ${ }^{63}$ Second, it was held that a transfer of the trust property by $\mathrm{T}$ to $\mathrm{D}$, even where it leads to the loss of B's beneficial interest, is not a disposition of that interest within the meaning of s $127 .^{64}$ There is thus a clear difference between the transfer (e.g. by a director) of a right vested in a company and the transfer by a trustee of a right held on trust for a company. ${ }^{65}$ The practical effect of each transaction - the loss of a company's right - may be the same, but the legal analysis differs as each transaction has a distinct formal structure. As Lloyd LJ had noted in an earlier case, a transfer by $\mathrm{T}$ to $\mathrm{D}$, where $\mathrm{D}$ is a bona fide purchaser of the legal

\footnotetext{
${ }^{60}$ See e.g. Lord Mance: "the English courts have regularly stated their willingness to enforce in personam trusts in respect of property abroad": [2017] AC 424 [24].

${ }^{61}$ The same analysis applies to other equitable property rights, such as the equity of redemption: see e.g. British South Africa Co v De Beers Consolidated Mines Ltd [1910] 2 Ch 502, 513-4

${ }^{62}$ Equity: A Course of Lectures (2nd ed, 1936, A H Chaytor \& W J Whittaker, eds, revised by John Brunyate, CUP, Cambridge, 1909) 17.

${ }^{63}$ This reasoning also supports the decisions of the English courts and the European Court of Justice in Webb $v$ Webb [1991] 1 WLR 1410; [1994] ECR I-1717, [1994] QB 696.

${ }^{64}$ This decisive point had not in fact been considered in the courts below, nor in oral argument before the Supreme Court, but was noted by the Justices only after that point, so that written submissions were invited: see [2017] AC 424, [9].

${ }^{65}$ As noted by e.g. Lord Mance at [53]-[55].
} 
estate for value without notice, "is as effective as it would be if [the trustee] could vest the beneficial title in the purchaser", but does not in truth involve such a transfer. D acquires title to the property from T, and is free to use that property for D's own benefit, but this is not because previously separate legal and beneficial interests have been re-united. It is rather because $\mathrm{D}$ has acquired a right from $\mathrm{T}$ and, given the bona fide purchase, there is no grounds on which equity can impose a restriction, in B's favour, on D's use of that right. ${ }^{66}$ There is, therefore, no disposition from B to D. ${ }^{67}$

\section{MISTAKEN, BUT VALID, TRANSFERS OF RIGHTS}

The argument of this chapter is that equitable intervention in favour of B has a characteristic form: it involves controlling the assertion of a right held by another, A. Whilst such intervention may, in practice, give B many of the advantages that go with other forms of legal relation, it is a mistake to equate the position in equity with those other forms of legal relation. So, as discussed in section 3, where a right is held on trust for the beneficiary, the beneficiary enjoys many of the practical advantages that come from holding such a right, but it is a mistake to regard the beneficiary as in fact holding that right. It has also been seen that this formal point does have substantive effects, particularly when regarding the obligations owed by third parties. Such an analysis can be linked to the historical development of equity as a secondary system: it provides a means to control rights established by the primary system of common law rules. As noted in section 2, when considering the rule against penalties, a debate as to whether a rule is best seen as equitable or not may sometimes be a debate as to whether the rule has such a secondary nature. Certainly, the form taken by such secondary rules can also be seen in areas which are not necessarily considered to be principally the domain of equity: this can be seen by examining some core aspects of the law of restitution.

\footnotetext{
66 [2017] AC 424 [51] (Lord Mance) and [2017] AC 424 [88] (Lord Sumption). See too Pilcher v Rawlins LR 7 Ch 259 (CA), where B's inability to bring a claim against D in such a case is seen as depending on a lack of equitable jurisdiction to reach $\mathrm{D}$.

${ }^{67}$ Although this point is not mentioned by the Supreme Court in Akers, such an analysis accords precisely with the interpretation of the phrase "disposition of an equitable interest" given by the House of Lords in Vandervell $v$ IRC [1967] 2 AC 291 when considering s 53(1)(c) of the Law of Property Act 1925. There, similarly, the transfer of legal title to shares by $\mathrm{T}$ to $\mathrm{D}$, with the permission of the beneficiary, $\mathrm{B}$, did not involve any disposition of the beneficial interest of $\mathrm{B}$ to $\mathrm{D}$.
} 
In the first article in the very first edition of the Harvard Law Review, James Barr Ames considered a puzzle that is still debated today: where a claimant, $\mathrm{C}$, makes a mistaken transfer of a right to D, why is it that, even if the transfer is valid, C's mistake may give rise to a claim by $\mathrm{C}$ to recover the value of the right transferred from $\mathrm{D}$ ? This will be referred to here as the 'mistaken transfer' case and the claim recognized as a 'personal restitutionary claim'. Ames argued that an analogy with the receipt of trust property may assist in understanding that claim. Where the trustee holds a right on trust and then transfers that right to a recipient (not a bona fide purchaser for value of the legal estate without notice) in breach of trust, the fact that the recipient has indeed acquired the right is not inconsistent with a holding that, if his conscience is affected by knowledge of the trust, he may come under a personal liability to the beneficiary as a constructive trustee. One broad way of understanding that result would be to say that the transaction between the trustee and the recipient was effective to transfer a right, but that it did not transfer the value of that right from the beneficiary to the recipient. A similar analysis might then be said to apply to the mistaken transfer case: the imposition of liability on the defendant is not inconsistent with the finding that the right was indeed transferred, as it can be said that, as a result of the mistake of the claimant, the value of the right has not been validly transferred. Or, in Ames' words: “a court of equity will compel the surrender of an advantage by a defendant whenever, but only whenever, upon grounds of obvious justice, it is unconscientious for him to retain it at another's expense", 68

Ames' argument repays careful consideration. ${ }^{69}$ The difficulties with it are clear from the analysis in section 3 above. First, in the case of the trust, the beneficiary (B) has no abstract entitlement to value. Indeed, as against parties other than B, the trustee $(\mathrm{T})$ has the same general liberty as an unencumbered owner to use the trust property for his or her own benefit, and to that extent, has an entitlement to the value of the trust property. In order to deny D, the recipient from $\mathrm{T}$, such a liberty as against $\mathrm{B}$, it is necessary to find a specific reason why $\mathrm{D}$ is under a duty to B: for example, because D acquired knowledge of the initial trust whilst still holding the trust property or its traceable proceeds. Second, there is of course a difference between the claim made by $\mathrm{B}$ against a recipient who retains trust property and the claim asserted by a mistaken transferor. The former case involves B's assertion that D has or had a specific right,

\footnotetext{
${ }^{68}$ J B Ames, 'Purchaser for Value Without Notice' (1887) 1 Harv L Rev 1, 3.

${ }^{69}$ For Ames's general influence on the development of the law of restitution, see A Kull, 'James Barr Ames and the Early Modern History of Unjust Enrichment' (2005) 25 OJLS 297.
} 
and is under a duty to B in relation to that right; whereas the mistaken transferor simply asserts that the recipient be ordered to pay a sum of money.

Ames' analysis may nonetheless be helpful. First, it is worth noting that his language of unconscientious retention, drawn from some foundational English cases, ${ }^{70}$ has been echoed more recently in Australian courts. ${ }^{71}$ Second, a link can be made at a more abstract level between the protection of the beneficiary against a recipient from the trustee and the protection of the mistaken transferor of a right. In the first case, the secondary nature of B's claim is clear: $\mathrm{B}$ accepts that the recipient, $\mathrm{D}$, holds a particular right, but argues that $\mathrm{D}$ is under a duty to $\mathrm{B}$ in relation to that right. The mistaken transferor's claim can also be seen as secondary, in the sense that the primary rules (which dictate that the transfer is valid, despite the mistake) are respected, but a claim is still asserted. Indeed, it can be argued that, like B's claim, the claim of the mistaken transferor provides a means of regulating the consequences of the defendant's acquisition of a right. ${ }^{72}$ On this view, the existence of the personal restitutionary claim helps to justify the operation of the rules which mean that the transfer of the right is valid, notwithstanding the transferor's mistake. ${ }^{73}$ There may be good reasons, particularly when considering certainty for third parties, for the law to stipulate that an apparent transfer is valid and that the recipient does indeed hold the right in question; but those reasons do not necessarily prevent the existence of the restitutionary claim. There are a range of means by which the law can recognize the claimant's interest in exercising autonomy as to a power to transfer rights. To the extent then that the restitutionary claim regulates the consequences, as between claimant and defendant, of the defendant's acquisition of a right, it can be seen as performing the role

\footnotetext{
${ }^{70}$ See e.g. Moses v Macferlan (1760) 2 Burr 1005, 1012 (Lord Mansfield): "This kind of equitable action, to recover back money, which ought not in justice to be kept, is very beneficial, and therefore much encouraged. It lies only for money which, ex aequo et bono, the defendant ought to refund." See too Clarke v Shee \& Johnson (1774) 1 Cowp 197, 199 (Lord Mansfield): "This is a liberal action in the nature of a bill in equity; and if, under the circumstances of the case, it appears that the defendant cannot in conscience retain the subject matter of it, the plaintiff may well support this action" and Parke B in Kelly v Solari (1841) 9 M \& W 54, 58: it is "against conscience" to retain money paid in the mistaken belief that the recipient is entitled to it "though a demand may be necessary in those cases in which the party receiving may have been ignorant of that mistake."

${ }^{71}$ See e.g. Australian Financial Services v Hills (2014) 253 CLR 560 at [65]-[76], and the the thorough exposition of Gummow J in Roxborough v Rothmans of Pall Mall Australia Ltd (2001) 208 CLR 516.

${ }^{72}$ See e.g. Cressman v Coys of Kensington (Sales) Ltd [2004] 1 WLR 2775, [24], where Mance LJ noted that, far from being a defence to the restitutionary claim, the fact that a registration scheme vested a right in the defendant was a pre-condition of that claim.

${ }^{73}$ See e.g. B McFarlane, 'Unjust Enrichment, Rights, and Value' in D Nolan and A Robertson (eds) Rights in Private Law (Oxford, Hart, 2012) 579, 591, 606. See too J Mee, 'Justifying Restitutionary Liability for Mistaken Payments' (paper presented at the Obligations IX conference) and n XX below.
} 
associated in this chapter with equity. So, whether or not one agrees with the historical claim in the first part of Cardozo's assertion that the action for money had and received is "equitable in origin and function", it is possible to agree with the second part of that assertion.

\section{EQUITABLE ESTOPPEL}

The analysis so far has picked out rules that regulate, in favour of B, either A's assertion, or A's acquisition, of a right. In relation to the trust, a consideration of the form of legal relations also cast doubt on the idea that a beneficiary of a trust should be seen as an "equitable owner" as this falsely suggests that his rights are equivalent to, or simply a weaker version of, those of a common law owner. Similar care must be taken with the concept of equitable estoppel.

There is a form of equitable estoppel which is indeed identical to the common law doctrine of estoppel by representation as it prevents the party bound, A, from making a particular assertion. This form of estoppel regulates the assertion not only of facts, but also of mixed matters of fact and law, and can thus be a means of regulating A's assertion of a right. To that extent the doctrine, recognized both in common law and at equity, ${ }^{74}$ can be a means of regulating a party's assertion of a right $;^{75}$ although it is not primarily focused on controlling the acquisition or exercise of rights, and does so only as a by-product of its evidential role in preventing the assertion of particular matters. Such a doctrine, of course, whilst it may be very useful to B in practice, cannot, in itself, operate as an independent means by which B can make a claim. Nor, as recognized in equity as well as at common law, ${ }^{76}$ can the doctrine apply where A has simply made a representation or promise as to A's future conduct: a preclusionary doctrine, whilst it can operate to prevent A denying that such a representation or promise was made, cannot determine the legal effects of such a representation or promise. ${ }^{77}$

\footnotetext{
${ }^{74}$ It is today more commonly associated with common law, but for examples of its application in equity, see e.g. Hunt v Carew (1649) Nels 46; Hunsden v Cheney (1690) 2 Vern 150 and see the helpful discussion in J Heydon

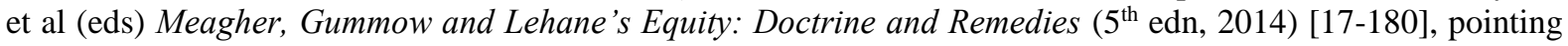
out that the "origins of estoppel by representation lay in Chancery."

${ }^{75}$ See e.g. Pickard $v$ Sears (1837) 6 A \& E 469.

${ }^{76}$ See e.g. Jorden v Money (1854) 5 HL Cas 185, which was an appeal from a court of Chancery.

${ }^{77}$ As noted by Gaudron J in Waltons Stores (Interstate) Ltd v Maher (1988) 164 CLR 387, 459.
} 
When other forms of equitable estoppel are considered, however, the link to the preclusive estoppel by representation survives in name only. First, consider promissory estoppel. Hughes $v$ Metropolitan Rwy $\mathrm{Co}^{78}$ has been instrumental in the development of the modern law of promissory estoppel. The decision provides a clear example of equity's second-order role in acknowledging the existence of a right, but then controlling the exercise of that right. A was prevented from exercising a contractual right to forfeit B's lease, as such a forfeiture would have allowed A to benefit from B's failure to complete repairs within a particular time, even though A had encouraged B to believe that B's inaction during a period when the parties where negotiating as to B's possible surrender of the lease would not lead to forfeiture of the lease. A did not thereby lose the contractual right; rather, A was prevented from asserting that right before the expiry of an additional period, so that the period in which negotiations had taken place did not count against B in assessing whether the repairs had been completed in time. As $\mathrm{B}$ was not claiming that $\mathrm{A}$ had lost the initial contractual right, there was no need for $\mathrm{B}$ to show that the parties' contract had been varied; B was instead protected through equity's control of A's assertion of the contractual right. Indeed, the relevant principle can be seen as responding to a possible defect in the general contractual rules controlling A's acquisition of the power to forfeit the lease: whilst the condition for A's acquisition of the right (B's failure to complete repairs in the contractually agreed six month period) had arisen, that condition consisted of particular action or inaction by $\mathrm{B}$, and it would be unjust for $\mathrm{A}$ to be free to enforce the right where B's decision to adopt that course of conduct was based on A's encouragement to B that A would not acquire or enforce the right. Certainly, A's action would seem to consist of precisely the sort of opportunistic taking advantage of a legal rule which equity, on one view, ${ }^{79}$ characteristically aims to prevent.

The reasoning in Hughes is thus characteristically equitable, in as much as it regulates, in B's favour, A's acquisition or enforcement of a right. It is, however, hardly a classic case of estoppel, and no mention was made of that term in the case itself. Certainly, the principle applied differs markedly from estoppel by representation, as it is based not on a representation as to an existing state of affairs but on A's encouraging B to believe something about A's future

\footnotetext{
78 (1877) 2 App Cas 439.

${ }^{79}$ See e.g. H Smith (n XX above).
} 
conduct. As later noted by Lord Denning MR, the main way in which the Hughes principle resembles estoppel by representation is in the fact that it cannot, by itself, operate as an independent cause of action: ${ }^{80}$ it is not a means by which A comes under a duty to B. This is simply a consequence of the nature of the principle, which seeks to prevent the unconscionable assertion of a right of A. Similarly, in Legione v Hateley, ${ }^{81}$ an equitable estoppel would have operated to prevent A taking advantage of a power to terminate the contract arising on B's failure to provide the purchase price at the agreed time. The closest common law cousin of such a doctrine is not estoppel by representation, but is rather the doctrine of waiver ${ }^{82}$ Indeed, the Hughes principle can be seen as closer to waiver (in that it shares the form of modifying A's ability to enforce a right) than to estoppel by representation.

In some jurisdictions, of course, equitable estoppel has also come to function as an independent cause of action. ${ }^{83}$ This happened first, it seems, in the "classic example of proprietary estoppel, [A's] standing by whilst one's neighbour [B] builds on one's land believing it to be his property, [which] can be characterized as acquiescence." ${ }^{84}$ This acquiescence principle can apply even where B is unaware of A's failure to act and so it does not seem to require any actual or implied representation to have been made by A to B. The use of estoppel language again notable by its absence from the cases first recognizing the principle ${ }^{85}$ - is therefore misleading. ${ }^{86}$ Indeed, from an early period, courts allowed the principle not only to give B an immunity against a potential claim of A, but also to impose a duty or liability on A, which might be satisfied only by A's transferring property, or paying money, to $\mathrm{B} .{ }^{87}$ Even if thus

\footnotetext{
${ }^{80}$ Central London Property Trust Ltd v High Trees House Ltd [1947] KB 130.

81 (1983) 152 CLR 406.

${ }^{82}$ This is also true of the (slightly different) doctrine applied in the High Trees case, which prevents D from enforcing a right against $\mathrm{C}$ where $\mathrm{D}$ has accepted a substitute performance as a discharge of that right: for discussion, see B McFarlane, 'Understanding Equitable Estoppel: From Metaphors to Better Laws' (2013) CLP 1.

${ }^{83}$ See e.g. Australia (e.g. Waltons Stores v Maher (1988) 164 CLR 387) and jurisdictions within the United States (see e.g. Restatement (Second) of Contracts, s 90).

${ }^{84}$ Fisher v Brooker [2009] 1 WLR 1764 (HL) at [62] (Lord Neuberger). See e.g. Sir John Romilly MR in Duke of Beaufort v Patrick (1853) 17 Beav 60, 74-5: "he who stands by and encourages an act, cannot afterwards complain of it, or interfere with the enjoyment of that which he has permitted to be done."

${ }^{85}$ Such as e.g. Duke of Beaufort v Patrick (1853) 17 Beav 60; Lord Cawdor v Lewis (1835) 1 Y \& C Ex 427.

86 For considerations of possible justifications of the principle see I Samet, 'Proprietary Estoppel and Responsibility for Omissions' (2015) 78 MLR 85.

${ }^{87}$ See e.g. Duke of Beaufort v Patrick (1853) 17 Beav 60; Lord Cawdor v Lewis (1835) 1 Y \& C Ex 427: "It is admitted to be a proper subject for equitable interference, where one party stands by and allows another to spend
} 
operating as a cause of action, however, the principle retains an element of a second-order function, as it arises to address a particular danger arising from the existence of a system of legal entitlements: it protects B against the risk of A's abusing B's mistaken belief as to B's existing entitlements. ${ }^{88}$

A more significant use of equitable estoppel as a cause of action has occurred in cases where B reasonably relies on A's promise in such a way that B would suffer a detriment were A wholly free to renege on that promise. It is clear in each of England ${ }^{89}$ and Australia ${ }^{90}$ that such a cause of action can arise where A's promise is to give B a right in relation to A's land, but English courts have been more reluctant than their Australian counterparts to extend the principle to other promises. ${ }^{91}$ There are two questions which must be separated when considering such extensions of equitable estoppel. First, there is a question as to outcomes (or, it might be said, substance): is there a good reason for recognizing a principle whereby A can have a duty to perform a non-contractual promise (or, at least, a liability to ensure $\mathrm{B}$ is not made worse off by reliance on that promise) where B would otherwise suffer a detriment as a result of B's reasonable reliance on A's promise? Second, there is a question as to means (or, it might be said, form): if there is a good reason for recognizing such a principle, should it be enforced through the doctrine of promissory estoppel? The problem of course is that the "estoppel" is wholly inapt to cover such a principle, as the defendant is not being estopped from asserting anything. Indeed, for those who think there is good reason for first order

money upon his lands without giving him notice of title... Whether the relief be a perpetual injunction, or an allowance by way of compensation, or a lease, must be determined by the result of the hearing."

${ }^{88}$ N McBride, The Humanity of Private Law (Oxford, Hart, 2019) 232 analyses the different strands of proprietary estoppel as doctrines which share the aim of preserving the legitimacy of private law, stating for example that, in the acquiescence case, a claim arises to prevent D 'bring[ing] private law into disrepute in the eyes of [B], who stands to lose out as a result of [A's] inconsistent treatment of him.' There is of course significant overlap between the aim identified by McBride of preserving the legitimacy of the law, and the second-order function identified in this chapter, but McBride's concept is broader and is used by him to explain, for example, why an objective standard of care is applied in the tort of negligence (ibid, 202-204). The basis of the second-order function identified in this chapter is closer to that suggested by S Smith, 'A Duty to Make Restitution' (2013) 26 Can JL Juris 157, 170, when describing certain liabilities imposed as "not responses to failures by defendants; they are responses to imperfections in the legal system itself."

${ }^{89}$ See e.g. Thorner v Major [2009] 1 WLR 776.

${ }^{90}$ See e.g. Sidhu v van Dyke (2014) 251 CLR 505.

${ }^{91}$ In Thorner v Major [2009] 1 WLR 776, [61], Lord Walker states that it is the relation of A's promise to some identified land that justifies B's acquisition of a claim against B. The principle does however seem to have been applied more broadly (e.g. in cases concerning intellectual property rights, such as Motivate Publishing $v$ Hello Ltd [2015] EWHC Ch 1544, [55]-[61]). For discussion see B McFarlane \& P Sales, 'Promises, Detriment, and Liability: Lessons from Proprietary Estoppel' (2015) 131 LQR 610. 
intervention in such cases, the link to promissory estoppel is unfortunate as it allows opponents of such a principle ${ }^{92}$ to cast doubt on it not by challenging its own merits, but rather by pointing out the differences between the principle and the type of second-order regulation of rights that is characteristic of equity and is evidenced by the decision in Hughes. Certainly, the use of the estoppel label may lead a judge to misunderstand the nature of the claim. ${ }^{93}$

In Waltons Stores v Maher, Brennan J answered the second question positively by finding no relevant distinction between a "change in legal relationships effected by a promise which extinguishes a right and a change in legal relationships effected by a promise which creates one." $" 94$ The analysis in this chapter points to exactly the opposite conclusion - there is a difference between a principle that controls the acquisition or assertion of an existing right (such as the principle in Hughes) and one that instead imposes a new duty or liability. That difference is recognized at common law: for example, the rules applying to a waiver of contractual rights differ from those applying to a variation of a contract. ${ }^{95}$ When a principle has a second-order nature, this opens up new possibilities for its justification: its explanation may be connected to the rules applying to the primary rights regulated by the second-order principle. ${ }^{96}$

The instability of Brennan J's contention can be seen in the subsequent development of the law of promissory estoppel in Australia: when it operates as a means to impose a new duty or liability on A, the requirement that the doctrine applies only to "a change in legal relationships" has been challenged and, in some cases, departed from. ${ }^{97}$ The legal relationship requirement makes sense when promissory estoppel performs its more established, second-order role of regulating the acquisition or assertion of rights, but it is very hard to justify when the impetus

\footnotetext{
${ }^{92}$ See e.g. the analysis of Handley AJA both judicially (e.g. Saleh $v$ Romanous (2010) 79 NSWLR 453) and in Estoppel by Conduct and Election (2006) 13.008.

93 As appears to have occurred, in the context of proprietary estoppel, in Lord Scott's judgment in Cobbe v Yeoman's Row Management Ltd [2008] 1 WLR 1752 [14].

94 (1988) 164 CLR 387, 425

${ }^{95}$ Most notably, consideration is not required: see e.g. Hickman v Haynes (1875) LR 10 CP 598.

${ }^{96}$ As noted in relation to personal restitutionary claims by e.g. B McFarlane, 'Unjust Enrichment, Rights and Value' in D Nolan \& A Robertson (eds) Rights and Private Law (Oxford, Hart, 2012).

${ }^{97}$ See e.g. Wv G (1996) 20 Fam LR 49; ACN 074971109 Pty Ltd (as Trustee for the Argot Unit Trust) v National Mutual Life Association of Australaisa Ltd (2008) 21 VR 351. For a full survey see A Robertson, 'Three Models of Promissory Estoppel' (2013) 7 J Eq 226, 240-243.
} 
for intervention is the first order concern of enforcing a promise, or of preventing $\mathrm{B}$ from suffering a detriment as a result of reliance on such a promise. For example, A's promise to enter into a contract to provide a service for B falls into the scope of Brennan J's formulation, whereas A's more direct promise simply to provide that service for B does not.

As a matter of substance, such a distinction is very hard to defend. Interestingly, however, it would be one means of preserving a (weakened) second-order form for equitable estoppel, even when operating as a cause of action. The argument would have to be that the existence of certain legal powers (such as the power to transfer a right, or to enter a contract), whilst advantageous overall, carries certain risks: a party may abuse such a power by, for example, causing another to suffer a detriment through reasonable reliance on a promise that such a power will be exercised. A second-order rule can then control the risk inherent in the powers established by the primary legal rules, by offering some protection to the relying party; just as a second-order rule allowing a personal restitutionary claim may control the risk inherent in those same legal powers by offering some protection to a party who mistakenly exercises them. ${ }^{98}$ Indeed, one might support this analogy between equitable estoppel and certain restitutionary claims by pointing to the similar language sometimes used by the courts in such cases $^{99}$ and also to the fact that, in each case, the rules operate to impose a liability, rather than an immediate duty, ${ }^{100}$ on the defendant.

\section{CONCLUSION}

The notion that equity looks to substance not to form can create a false opposition: attention to the form of legal relations is a crucial step in considering the justification of particular

\footnotetext{
${ }^{98}$ See B McFarlane, 'Unjust Enrichment, Rights, and Value' in D Nolan and A Robertson (eds) Rights in Private Law (Oxford, Hart, 2012) 579, 591, 606 and J Mee, 'Justifying Restitutionary Liability for Mistaken Payments' (paper presented at the Obligations IX conference).

${ }^{99}$ See e.g. the reference to unconscionability as an overarching concept, and the making of a direct comparison between restitution and equitable estoppel in both Pitt v Holt [2013] 2 AC 108, [126]-[128] (Lord Walker) and Australian Financial Services Ltd v Hills (2014) 253 CLR 560, [65]-[76] (Hayne, Crennan, Kiefel, Bell and Keane $\mathrm{JJ})$.

${ }^{100}$ For a liability-based analysis of the personal restitutionary claim see 'S Smith, 'A Duty to Make Restitution' (2013) 26 Can JL Juris 157; for a liability-based analysis of equitable estoppel when operating as a cause of action, see B McFarlane, 'Equitable Estoppel: Neither One Thing Nor One Other' in S Degeling, J Edelman \& J Goudkamp (eds) Contracts in Commercial Law (Sydney, Thomson Reuters, 2016).
} 
substantive outcomes. In the examples discussed in this chapter, the application of a particular formal analysis has favoured specific practical results. The basic claim made here is that, in many cases, the importance and distinctiveness of equitable rules lies in the fact that such rules regulate, in favour of a specific claimant, the enforcement or acquisition of a right of the defendant. This means, first, that equitable rules often produce different effects from common law rules to which they are linked. This was seen by considering the trust, where it was argued that there are significant formal differences between the legal relations involved in an equitable interest on the one hand and a legal property right on the other. Those formal differences have important substantive effects when considering the obligations of third parties. For example, it was argued that the existence of a trust does not impose on third parties an immediate duty to the beneficiary, nor does it give a beneficiary an abstract entitlement to value that can be asserted against third parties. Rather, such third parties are better understood as being under a liability: it is possible that their own enforcement of acquisition of particular rights (i.e. the trust property or its traceable proceeds) may be controlled in favour of the beneficiary.

It was then argued that this second-order model, whilst reasonably clear in the case of trusts, is also relevant to other parts of the law of obligations. Indeed, as seen when considering restitutionary claims based on mistaken transfers of rights, the model can apply in areas which are not always thought of as dependent on equitable intervention. The important point here is not as to the jurisdictional origin of the rules, but is rather as to their form. The second order nature of the rules may help to resolve certain puzzles as to their justification. In particular, such rules can be seen as helping to mitigate the effects of primary rules (for example as to when the transfer or creation of a right is or is not valid) and thus limiting some of the risks that arise when the law recognizes a power to transfer or create rights. Indeed, in relation to each of the restitutonary claim and equitable estoppel, it may be that the answer to the substantive question as to the appropriate scope of a cause of action depends on determining the formal function of the underlying principle. So, is the personal restitutitonary claim arising in the case of a mistaken transfer of rights part of a broader primary principle imposing a prima facie duty on $\mathrm{A}$ in cases where $\mathrm{A}$ is enriched (in whatever form) at B's expense, ${ }^{101}$ or is it better seen as a more limited secondary rule which exists to mitigate the risks created by the existence

\footnotetext{
${ }^{101}$ This was essentially Birks' argument in chapter 1 of Unjust Enrichment $2^{\text {nd }}$ edn (Oxford, OUP, 2005) where the key feature of a mistaken payment is seen as the mistaken transfer of value, rather than as the mistaken transfer of a right.
} 
of legal powers to transfer or create rights, therefore applying to impose a liability on A only where such a power has been exercised $?^{102}$ Similarly, is the claim arising where B reasonably relies to his or her detriment on a promise by A part of a broader primary principle imposing a duty on A whatever the content of A's promise, or is it better seen as a more limited secondary rule which exists to mitigate the risks created by the existence of legal powers to transfer or create rights, therefore applying to impose a liability on A only where A has promised to exercise such a power in B's favour? To answer such questions within the context of established judicial rules, whether such rules arose at common law or in equity, we must look to form as well as to substance.

${ }^{102}$ Such an argument is consistent with e.g. B McFarlane, 'Unjust Enrichment, Rights and Value' in D Nolan \& A Robertson (eds) Rights and Private Law (Oxford, Hart, 2012). 